\title{
Urbanization, Industrialization and Inequalities in Africa: does threshold matter?
}

\author{
Richard ZOGO EKASSI ${ }^{1}$, Bruno Emmanuel ONGO NKOA ${ }^{2}$, Jacques Simon SONG ${ }^{3}$ \\ ${ }^{1}$ University of Yaounde II, Cameroon. \\ ${ }^{2}$ University of Dschang, Cameroon. \\ ${ }^{3}$ University of Dschang, Cameroon.
}

\begin{abstract}
:
This paper examines the impact of urbanization and industrialization on observed inequalities in a sample of48 African countries. We specify and estimate a panel data model using the Generalized Method ofMoments-System (GMM-S) over the period 1980-2016 along the different dimensions of inequality. Ourresults show that urbanization increases income, environmental and housing inequalities in Africa, whileindustrialization reduces them. Our results remain robust with the use of Panel Smooth TransitionRegression Model (PSTR) and Panel Transition Regression Model (PTR). We suggest taking into accountthe disparities identified in the inclusive urbanization and industrialization policies of African cities.
\end{abstract}

Keywords: Africa, GMM-S, Industrialization, Inequalities, Urbanization.

JEL Classification: D63, F18, L16, L52.

\section{Introduction}

Two major facts have characterized economic development in Africa for at least three decades: rapid urbanization and steady deindustrialization. Africa is rapidly urbanizing. From 1960 to 2010, its urbanization rate increased from $15 \%$ to $40 \%$ and is estimated to reach $60 \%$ by 2050 (UNDP, 2017). If the upward trend continues, African cities will be home to nearly a quarter of the world's urban population or about 1.2 billion people. Strong urbanization favors investment, infrastructure construction, and the reduction of unemployment. However, it can lead to the creation and maintenance of inequalities, thus maintaining the vicious circle of poverty and insecurity (Lachaud, 2006).

Manufacturing value added gradually increased along with GDP per capita in the early 2000s. However, it has been declining, showing the failure of African countries to maintain the sector's growth momentum. This is attributed to the decline in manufacturing productivity, whose average growth rate fell from 7.3 percent in 2000-2008 to 3.5 percent in 2009-2014. A dynamic industrial process would contribute to reducing inequality in Africa. This can happen if and only if an industrialization plan is adopted as well as an urbanization program in Africa.

There are three types of inequalities in Africa. First, economic inequalities are marked by the difference in income and therefore the Gini coefficient remains an effective indicator of measurement. Second, social inequalities are captured by the percentage of the urban population living in slums and shantytowns. Finally, environmental inequalities are explained by an unequal sharing of natural resources, the absence of green space and urban pollution. According to UN-Habitat (2010), African cities are by far more unequal with a Gini index of 0.529, compared to a Gini index of 0.509 for cities in Latin America and the Caribbean.

Starting from the fact that strong urbanization increases inequality, the analysis of industrialization is somewhat different. Industrialization is associated with a shift from the primary sector to the secondary and tertiary sectors. For Cadot et al, (2017) industrial transformation has contributed to a reduction in income 
poverty in Africa since the late 1990s. Manufacturing Value Added (MVA) as a percentage of GDP has declined in Sub-Saharan Africa from 12.02\% in 1995 to 10.6\% in 2015 (WDI, 2018).

This article contributes to the literature on this under-researched topic. Theoretically, the article examines the simultaneous effects of urbanization and industrialization on inequality in Africa. It is unlikely that any specific study exists, let alone Africa, that is under the umbrella of population growth and industrialization. Empirically, the paper makes use of the Generalized Moment Method and analyzes the robustness of the results by applying the Panel Smooth Transition Regression model (PTSR) and the Panel Transition Regression (PTR). Strategically, the repercussions of the recent demographic crisis affect African countries, with the decline in Official Development Assistance (ODA), imports and investments (UNCTAD, 2009).

The rest of the article is divided into five sections. The second presents a summary of the state of the art. The third illustrates the stylized facts. The fourth outlines the methodological strategy. The five discusses the results, and the last concludes with some policy recommendations.

\section{Synthesis of the state of the art}

\subsection{Urbanization and Inequality}

The literature classifies the determinants of inequality into three groups. First, economic determinants such as population density, natural resources, financial globalization, domestic investment, trade globalization, government consumption expenditure, income level Anyanwu et al. 2016; Fosu, 2018). Second, social determinants such as household size, education level, government assistance, unemployment (Mahmood and Noor, 2014). Finally, institutional determinants such as democracy, ethnolinguistic fragmentation, quality of governance, colonial origin (Brunori et al., 2015; Shimeles and Nabassaga, 2018). However, Bonaiuto et al, (1999) found that urbanization by promoting population density mitigates income inequalities and densifies environmental inequalities through olfactory. Lachaud (2006) found that urbanization is accompanied by demographic changes and migrations that generate environmental inequalities in Africa. Behrens et al, (2012), Aissaoui et al, (1999) report that urbanization, by changing the structure of cities, increases habitat and environmental inequalities. Kanbur and Zhuang (2013), Chen and Zhou (2005) in their studies on Asian countries, concluded that urbanization increases income inequality. Wei et al, (2017), Chen et al, (2016) found that urbanization increases income gaps between urban and rural areas. On the other hand, Wu and Rao (2017) concluded that inequality is less exacerbated in high-income areas due to urbanization than in rural areas with large migration flows. In contrast, Liddle (2017) finds a non-significant effect of urbanization on inequality.

\subsection{Industrialization and Inequality}

The role of industrialization on inequality can be traced back to the seminal work of Williamson (1965), who laid the groundwork for the theory of developmental phases and illustrated regional disparities through the inverted-U curve. Subsequently, Krugman (1994) established that industrialization generates disparities through the spillover effects of the modernization process of economies. Davis and Henderson (2003) established that industrialization favors the emergence of urban polarization, and accentuates income inequalities. Chong and $\mathrm{Wu}(2014)$ reported that structural transformation and industrial modernization have contributed to mitigating income inequality. Mehic (2018) found that industrialization based on modern exploitation of natural resources exacerbates income inequality. Chen (2010), Chuan (2008) using Simultaneous Equation Models in a sample of developed countries, found that industrial development and urbanization had reduced income disparities between urban and rural areas. On the other hand, Zhang (2016) found that urbanization and industrialization help to reduce income inequality in China.

\section{Some stylized facts}

Three stylized facts emerge from the observation of urbanization, industrialization and inequality in Africa.

\section{- Africa is urbanizing at an increasing rate}

The level of urbanization in Africa has structurally increased from $18.6 \%$ in 1960 to $40.43 \%$ in 2015 . According to projections provided by World Urbanization Prospects (2014), in 2035 urbanization in Africa could reach $49.3 \%$ and settle at 55.9\%. The improvement in the growth of Gross Domestic Product (GDP) would play an important role. 
- Manufacturing value added remains very low in Africa

Africa has been characterized by low manufacturing value added since 1995, as a result of poor governance, political instability, a weak investment climate, poor business performance, lack of effective integration, a shortage of skilled labor, low technological competence, inadequate energy supply, poor infrastructure, and especially poor diversification of the productive structure.

\section{- Social and environmental vulnerabilities are changing in Africa}

Rapid urbanization has increased pressure on housing, living conditions, and inequality. The problems of housing and living conditions suggest that slums are on the rise in African cities. In some large African cities, up to $80 \%$ of the population lives in slums. These figures have been increasing steadily since 1990 . Figure 1 below shows that income inequalities are increasingly observed and are accompanied by housing inequalities, which, due to the lack of a sustainable waste management policy, promote pollution, deteriorating air quality and hindered natural resource management. Despite its low production, Africa is expected to have 442 million tons of urban waste per year by 2025 .

Figure 1: Distribution of inequalities in Africa

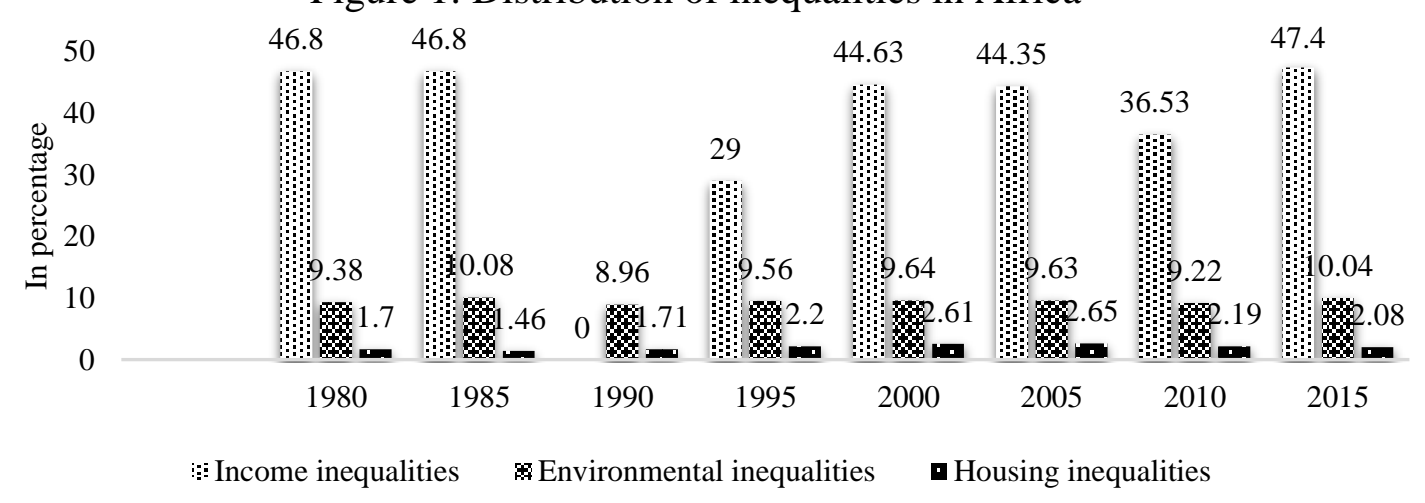

Source : Auteurs, from World Bank Database (2018).

\section{The empirical model, the estimation technique and the data}

\subsection{The empirical model}

The model is inspired by Wu and Rao (2017), who pointed out that income inequality increases or remains unchanged during the processes of urbanization and industrialization. The logarithmic equation of income inequality is described by model (1).

$$
I^{2}=P_{1} I_{1}^{2}+P_{2} I_{2}^{2}+P_{1}\left(Y_{1}-Y\right)^{2}+P_{2}\left(Y_{2}-Y\right)^{2}
$$

Where $\mathrm{Y}_{1}, \mathrm{Y}_{2}, I_{1}^{2}$ and $I_{2}^{2}$ are the logarithms of the means and variances in the two respective sectors. P_1 and $P_{-} 2$ are the respective population shares of the two sectors. If aggregate income is distributed according to equation (2),

$$
\begin{aligned}
& Y=P_{1} Y_{1}+P_{2} Y_{2} \\
& P_{1}+P_{2}=1 \quad\left(P_{1}, P_{2} \geq 0\right)
\end{aligned}
$$

By substituting equations (2) and (3) into equation (1) we can write:

$$
I^{2}=A P_{1}^{2}+B P_{1}+C
$$

$$
\text { With } A=-\left(Y_{1}-Y_{2}\right)^{2} ; B=\left(I_{1}^{2}+I_{2}^{2}\right)+\left(Y_{1}-Y_{2}\right)^{2} \text { and } \mathrm{C}=I_{2}^{2}
$$

Under the assumption of differential income levels in the rural and urban sectors, equation (4) shows an inverted U-shaped relationship between income inequality and population share in the urban sector.

Following the specification of Anyanwu et al, (2016), which incorporates more explanatory variables, we specify the model to be estimated below.

$$
\text { Inequalities }_{i t}=\alpha \text { Inequalities }_{i t-1}+U_{i t} \pi+X_{i t} \gamma+t_{t}+\delta_{i}+\varepsilon_{i t}
$$




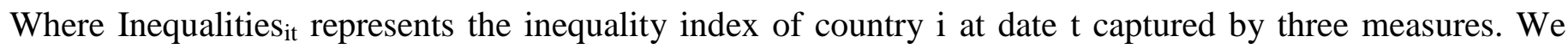
postulate that urbanization and industrialization affect inequality along three dimensions: $(i)$ the income dimension, which describes the income gap between the affluent who can afford better living conditions and those forced to live below the monetary poverty line; (ii) the housing inequality dimension, which differentiates between those living in slums and those living in well-built houses; (iii) the environmental dimension, which is experiencing renewed interest to its unrationalized management, creates further inequalities. Inequality $(i t-1)$ is the lagged inequality index of a period; $U_{i t}$ is the matrix of variables of interest composed of urbanization rate, degree of urbanization of African cities, industrialization and degree of industrialization of African cities. The urbanization rate is measured by the share of the population living in cities, and industrialization is approximated by manufacturing value added as a ratio of GDP. $\mathrm{X}_{\text {it }}$ is the matrix of other explanatory variables. $t_{t}, \delta_{i}$, et $\varepsilon_{i t}$ are respectively the time fixed effects, the country fixed effects and the remaining disturbance.

The extended model takes the following form :

$$
\begin{aligned}
& \text { Inequalities }_{i t}=\alpha_{0}+\alpha_{1} \text { Inequalities }_{i t-1}+\pi_{1} \text { Urban }_{i t}+\pi_{2} \text { Urban }_{i t}^{2}+\phi_{1} \text { Indus }_{i t}+\phi_{2} \text { Indus }_{i t}^{2}+\gamma_{1} G D P / H b t_{i t} \\
& +\gamma_{2} \text { Dom_inv }_{i t} \gamma_{3} \text { FDI } / G D P_{i t}+\gamma_{4} \text { Unemployment }_{i t}+\gamma_{5} \text { Governance }_{i t}+\gamma_{6} \text { Democracy }_{i t} \\
& +t_{t}+\delta_{i}+\varepsilon_{i t}
\end{aligned}
$$

The income inequality index is measured by the Gini coefficient. Housing inequality is measured by the rate of the population living in slums or non-decent housing. Environmental inequalities are captured by the number of people living on the margins of nature protection or living in insalubrious conditions marked by poor garbage management.

As shown by Kuznets (1955), the variables of interest make it possible to determine the breakpoint and thresholds of the transition variables, in the form of an inverted U-shaped relationship between urbanization and inequality on the one hand, and between industrialization and inequality on the other.

The other explanatory variables include: $(i)$ real GDP per capita which captures the standard of living of the country's population. We postulate with Fosu (2018) that income disparities in Africa increase inequalities in urban areas; (ii) Domestic investment, approximated by gross fixed capital formation; (iii) Foreign direct investment, which is captured by the inflow of FDI relative to GDP, tends to maintain strong inequalities (Meunié, 2004); (iv) the unemployment rate, measured by the number of unemployed young people relative to the total number of young people. It naturally increases inequalities; (v) local governance and (vi) the low level of democracy result in high inequalities in urban areas. These are indices between -2.5 and 2.5.

\subsection{The estimation technique}

We used Ordinary Least Squares (OLS), Generalized Least Squares (GLS) and Generalized Moment Method (GMM) estimates introduced by Arellano and Bond (1991) and Arellano and Bover (1995). Subsequently, Blundell and Bond (1998) developed the System-GMM estimator, which is more appropriate for solving the problems of multicollinearity, endogeneity and omitted variable bias. While the SystemGMM seems theoretically more efficient than the Difference-GMM, it uses more instruments than the latter, which makes it inappropriate. The S-GMM has at least three advantages: (i) first, it provides unbiased, convergent and efficient estimators in the presence of lagged variables; (ii) second, it takes into account unobservable geographical factors, such as climate, openness to the sea and even the heterogeneity of monetary policies, which can have an impact on the attractiveness of countries, economic growth and trade openness; (iii) finally, it allows us to correct for the simultaneity bias between the variables of interest and control (Wooldridge, 2013). However, the absence of autocorrelation in the residuals ensures that the estimators are obtained. Although the measures of the institutional variables are objective, we cannot rule out the possibility of measurement errors. One solution is to introduce instruments and test their validity with Sargan and Hansen tests (Roodman, 2009).

\subsection{Data sources}

The data came from three main sources. First, data on macroeconomic variables are from the World Bank Database. Second, data specific to inequality are from Standardized World Income Inequality Database 
(SWIID) and UN Habitat (2018). Third, data specific to institutional variables are from PolityIV Project Online (2018). The study covers 48 countries in Africa (Appendix 1).

The time horizon dictated by data availability covers the period from 1980 to 2016. The descriptive statistics in Table 1 show the same number of observations. The correlations between the different variables used are not so high as to create serious problems of multicollinearity (Appendix 2).

Table 1: Descriptives statictics

\begin{tabular}{|l|c|c|c|c|c|}
\hline Variables & Observations & Mean & $\begin{array}{l}\text { Standard } \\
\text { Deviation }\end{array}$ & Minimum & Maximum \\
\hline Income inequalities & 1776 & 4.180236 & 13.26466 & 0 & 65.8 \\
\hline Housing inequalities & 1776 & 1.968736 & 4.484276 & 0 & 31.50345 \\
\hline Environmental inequalities & 1776 & 6.166841 & 8.20723 & 0 & 57.98816 \\
\hline Industrialization & 1739 & 2.986493 & 9.919929 & -72.23093 & 128.3681 \\
\hline Industrialization2 & 1776 & 105.0328 & 549.993 & 0 & 16478.36 \\
\hline Urbanization & 1776 & 33.00146 & 15.14166 & 0 & 87.366 \\
\hline Urbanization2 & 1776 & 1318.237 & 1167.902 & 0 & 7632.818 \\
\hline GDP/Habitant & 1776 & 1.104376 & 7.364146 & -50.23014 & 140.5011 \\
\hline Domestic investment & 1776 & 18.6985 & 23.74753 & 0 & 115.971 \\
\hline Foreign direct investment & 1776 & 7.460811 & 8.335728 & 0 & 41.6 \\
\hline Unemployment & 1776 & 64.92792 & 50.39488 & 0 & 531.7374 \\
\hline $\begin{array}{l}\text { Governance normalized } \\
\text { index }\end{array}$ & 1776 & 3.538611 & .6300974 & 1.789827 & 5.249671 \\
\hline Democracy normalized index & 1776 & 3.474647 & .6854607 & 1.331127 & 5.130958 \\
\hline
\end{tabular}

Source: Authors.

\section{Estimates and discussion of results}

\subsection{The results of the basic model}

\section{Effects of urbanization and industrialization on income inequality}

Overall, the results show that income inequality in the previous year has a memory effect and significantly increases income inequality in the current year. The results suggest that urbanization increases income inequality (model 1). Plausible explanations are migration flows that transform the rural-urban gap into an intra-urban problem with the appearance of disparities. Consequently, rapid and uncontrolled urbanization in Africa also generates income inequality, which becomes a serious, widespread, and overlooked feature. The high squared rate of urbanization reduces income inequality showing an inverted U-shaped relationship between the two variables. FDI increases income inequality. This result is explained by the fact that incoming FDI flows are accompanied by product and process innovations that contribute to crowding out local initiatives by young entrepreneurs, who for lack of financial means find themselves in a situation of technical unemployment.

Table 2 : Urbanization, industrialization and income inequalities

\begin{tabular}{|l|c|c|c|}
\hline & \multicolumn{3}{|c|}{ Estimation technique: S-GMM } \\
\hline & \multicolumn{3}{|c|}{ Dependante variable: Income inequalities } \\
\hline & $(\mathbf{1})$ & $\mathbf{( 2 )}$ & $\mathbf{3})$ \\
\hline Income inequalities(t-1) & $0.108^{*}$ & $.970036^{* * *}$ & $.0675^{* * *}$ \\
\hline & 0.087 & 0.000 & .0000 \\
\hline Urbanization & $0.079^{* * *}$ & & $.0109 * * *$ \\
\hline & 0.001 & & 0.000 \\
\hline Urbanization 2 & $-.001^{* * *}$ & & $-.0083^{* *}$ \\
\hline & 0.000 & & 0.028 \\
\hline Manufacturing value added & & $.00158^{*}$ & $.0004 * *$ \\
\hline & & 0.064 & 0.043 \\
\hline Manufacturing value added 2 & & $-.00913^{*}$ & $-.2049 * * *$ \\
\hline & & 0.083 & 0.000 \\
\hline
\end{tabular}




\begin{tabular}{|l|c|c|c|}
\hline GDP/habitant & 0.0195 & $-.02193^{* * *}$ & $-.099^{*}$ \\
\hline & 0.801 & 0.008 & 0.057 \\
\hline Domestic investment & 0.0092 & $.0438^{*}$ & -.0057 \\
\hline & 0.244 & 0.063 & 0.362 \\
\hline Foreign direct investment & $.16^{* * *}$ & $.0121^{* *}$ & $.0085^{*}$ \\
\hline & 0.000 & 0.024 & 0.063 \\
\hline Unemployment & -.0006 & $-.0044^{* * *}$ & .0749 \\
\hline & 0.112 & 0.000 & 0.746 \\
\hline Governance normalized index & 0.373 & $.0215^{* *}$ & $-.861 * *$ \\
\hline & 0.477 & 0.010 & 0.017 \\
\hline Democracy normalized index & -0.856 & $-.0530^{* *}$ & $-.0382 * *$ \\
\hline & 0.193 & 0.021 & 0.042 \\
\hline Constant & $2.07 * * *$ & .17175 & .923 \\
\hline & 0.000 & 0.331 & 0.475 \\
\hline Observations & 1702 & 1692 & 1692 \\
\hline Countries & 48 & 47 & 47 \\
\hline AR(1) & 0.000 & 0.000 & 0.000 \\
\hline AR(2) & 0.785 & 0,674 & 0,942 \\
\hline
\end{tabular}

Notes : *p<0.1;**p<0.05;***p<0.01.

Source : Authors.

The results of model 2 show that manufacturing value added, domestic investment and the quality of governance have positive and statistically significant effects on income inequality. A key explanation is that industrialization is accompanied by low productivity, limited job creation, large infrastructure and service deficits, a large informal sector, and weak institutional capacity and systems that impede structural transformation. This situation not only prevents cities from functioning better but also makes it impossible to develop economic development strategies.

On the other hand, accelerated industrialization, GDP/capita, unemployment, and democracy contribute to a significant reduction in income inequality. The alignment of an industrial policy specific to African countries strengthens the capacities of economic agents who, in order to meet their needs, engage in both formal and informal activities that contribute, albeit relatively, to reducing income inequalities.

Urbanization and industrialization in Africa, for lack of a sustainable policy, do not improve welfare and exacerbate income inequality (model 3). On the other hand, accelerated urbanization and industrialization contribute to reduced income inequality. Indeed, labor-intensive industrialization and successful urbanization, through national and regional city systems, are key drivers of youth productivity due to agglomeration economies, and significantly reduce income inequality. Achieving this outcome depends on good governance and intrinsic democracy. This result is consistent with Zhang (2017).

\section{Effects of urbanization and industrialization on environmental inequalities}

The results show that the environmental inequalities of the previous year have a memory effect, and significantly increase the environmental inequalities of the current year. However, urbanization and domestic investments contribute significantly to increasing environmental inequalities in Africa. Indeed, urbanization implicitly induces greenhouse gas emissions, which is not inevitable provided that cities work towards sustainable development.

Table 3: Urbanization, industrialization and environmental inequalities

\begin{tabular}{|l|c|c|c|}
\hline & \multicolumn{3}{|c|}{ Estimation technique: S-GMM } \\
\hline & Dependante variable: Environmental inequalities \\
\hline & $(\mathbf{1})$ & $\mathbf{( 2 )}$ & $(\mathbf{3})$ \\
\hline Environmental inequalities(t-1) & $0.245^{* * *}$ & .9309 & $.1995^{*}$ \\
\hline & 0.000 & .9139 & 0.094 \\
\hline Urbanization & $0.118^{* * *}$ & & $.0089 * * *$ \\
\hline
\end{tabular}




\begin{tabular}{|c|c|c|c|}
\hline & 0.001 & & 0.000 \\
\hline \multirow[t]{2}{*}{ Urbanization 2} & $-.0014 * * *$ & & $-.0289 * *$ \\
\hline & 0.002 & & 0.028 \\
\hline \multirow[t]{2}{*}{ Manufacturing value added } & & $.00866 *$ & $.0054 * *$ \\
\hline & & 0.061 & 0.043 \\
\hline \multirow[t]{2}{*}{ Manufacturing value added 2} & & $-.0054 * * *$ & $-.0021 * * *$ \\
\hline & & 0.000 & 0.000 \\
\hline \multirow[t]{2}{*}{ GDP/habitant } & -0.0003 & $-.0120 * * *$ & $.00018 *$ \\
\hline & 0.988 & 0.008 & 0.057 \\
\hline \multirow[t]{2}{*}{ Domestic investment } & $0.055 * * *$ & $-.00801 * * *$ & -.0061 \\
\hline & 0.000 & 0.005 & 0.362 \\
\hline \multirow[t]{2}{*}{ Foreign direct investment } & 0.027 & .00208 & $.00335 *$ \\
\hline & 0.296 & 0.312 & 0.063 \\
\hline \multirow[t]{2}{*}{ Unemployment } & $-.015 * * *$ & $.0106^{*}$ & .0065 \\
\hline & 0.000 & 0.073 & 0.746 \\
\hline \multirow[t]{2}{*}{ Governance normalized index } & -0.035 & $.00069 *$ & $-.00055 * *$ \\
\hline & 0.946 & 0.087 & 0.017 \\
\hline \multirow[t]{2}{*}{ Democracy normalized index } & -0.011 & $.37255 * * *$ & $-.5849 * *$ \\
\hline & 0.980 & 0.000 & 0.042 \\
\hline \multirow[t]{2}{*}{ Constant } & $2.43 * * *$ & $.2316 * *$ & .4612 \\
\hline & 0.000 & 0.044 & 0.475 \\
\hline Observations & 1702 & 1692 & 1692 \\
\hline Countries & 48 & 47 & 47 \\
\hline$A R(1)$ & 0.000 & 0.000 & 0.000 \\
\hline$A R(2)$ & 0.033 & 0.983 & 0.983 \\
\hline
\end{tabular}

Notes : *p<0.1;**p<0.05;***p<0.01.

Source : Authors.

The lack of a good urbanization policy forces residents and workers to suffer from noise, fumes and unpleasant emanations that create a visually unpleasant environment that is detrimental to their well-being. There are also risks of epidemics, cyclones, landslides, water and soil pollution. This result shows an inverted U-shaped relationship. Achieving this goal is the responsibility of objective and sustainable policies that reduce environmental inequalities. These results are consistent with those obtained by Ademe (2004), Behrens et al. (2012).

Manufacturing value added, unemployment, and the level of democracy have positive and statistically significant effects on environmental inequality. Indeed, industrialization in Africa is characterized by noncompliance with environmental standards. As a result, this situation, due to climate change, contributes to deteriorating air quality and moderate, often localized, environmental impacts (odors, noise, pollution) and increases the environmental and carbon footprints of cities due to automobile traffic. It has also been observed that the unemployment situation in African cities, due to the lack of restrictions on zoning and density, favors the establishment of small informal industries that cause nuisances to the immediate environment through pollution, noise and odors. Accelerated industrialization, GDP/capita, and domestic investments contribute to significantly reduce environmental inequalities.

Indeed, the alignment of industrial policy forces firms to exploit the productive forces of cities, and to respond to urban demand without policy support, in the form of a favorable regulatory framework, training and skills-building opportunities, and a prioritization of infrastructure that supports value chains.

Urbanization, industrialization, GDP/capita, and FDI flows contribute to increased income inequality through informal settlements and slums that pose a threat to urban environmental well-being. Specifically, these aspects deprive a generation of access to education and health, and are generally perceived as poverty traps. On the other hand, accelerated urbanization and industrialization, resilient, green, cross-sectoral, and 
multi-level governance, and improved intrinsic democracy make it possible through multimodal options to ensure environmentally friendly urban mobility.

\section{Effects of urbanization and industrialization on housing inequalities}

The results show that the previous year's housing inequality has a memory effect, and significantly increases the current year's housing inequality. However, urbanization, GDP/capita, and governance have positive and statistically significant effects on housing inequality in Africa. This result is explained by the fact that urbanization implicitly induces poor housing conditions, overcrowding, noise pollution, unemployment, poverty, and cultural dislocation that exacerbate health problems, anxiety, depression, insomnia, and substance abuse. Overwhelmed by the pace of this urbanization, municipalities and health authorities are struggling to cope. Likewise, anarchic urbanization and strong tensions on the basic infrastructure strongly affect living conditions, the natural environment and weaken the ecosystem.

Table 4: Urbanization, industrialization and housing inequalities

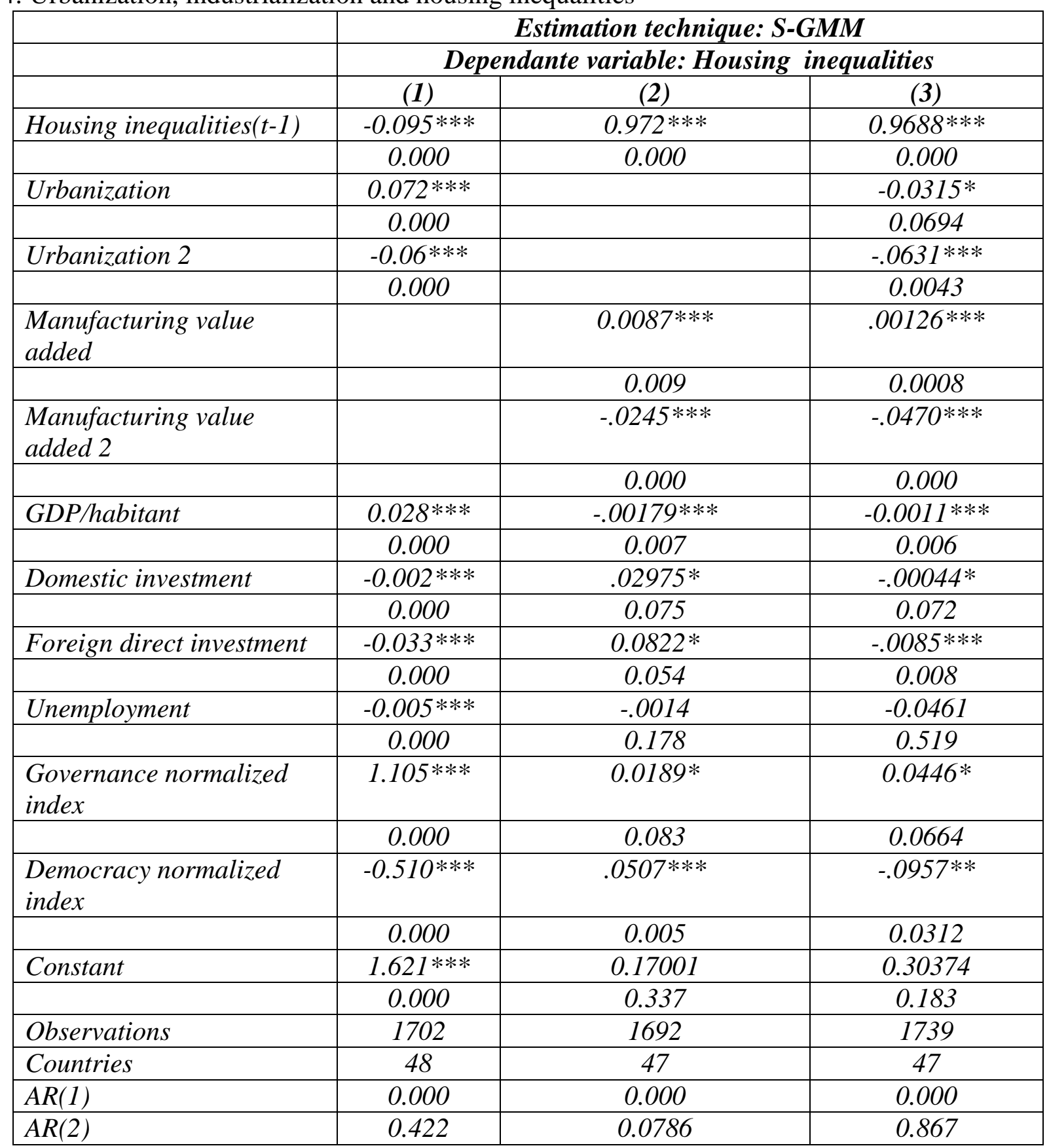

Notes: $* p<0.1 ; * * p<0.05 ; * * * p<0.01$.

Source : Authors.

Three observations can explain these results. First, the low level of income that characterizes African wage earners and non-wage earners, who are unable to afford an average home due to the high cost of living. 
Second, the quality of governance is poor due to a weak legal framework and endemic problems of corruption. Finally, the weakness of the institutional framework limits the intrinsic logic desired by politicians and crowds out all social considerations of the populations. On the other hand, urbanization squared, domestic investments, FDI and democracy are contributing to reducing housing inequalities, due to the renewed interest of African authorities to implement sustainable urbanization, translated by the advent of investments in modern housing, and to reframe informal activities resulting from unemployment through small-scale industrialization and to contribute more to GDP.

Manufacturing value added, domestic investment, governance and FDI have positive and statistically significant effects on housing inequality. The explanation lies in the fact that industrialization in Africa is essentially characterized by a lack of respect for principles. As a result, unsuitable investments are favored, which, for lack of a housing policy, increase housing inequalities. In some countries, the establishment of FDI is done to the detriment of anarchic constructions, forcing some inhabitants to settle in slums. However, accelerated industrialization and GDP per capita are contributing to a significant reduction in housing inequalities. Indeed, the alignment of an industrial policy forces companies forced to exploit the productive forces of the cities to respond to urban demand by building housing beforehand.

Taking urbanization and industrialization into account shows a reduction in housing inequalities through sectoral policies that create jobs and access to basic social services. Achieving this result depends on an acceptable level of income, pro-poor domestic investment, market-creating FDI, and sustainable democracy through agglomeration economies that make the urban habitat more attractive. The results corroborate those of Wei et al. (2017).

\subsection{Robustness analysis}

To ensure the robustness of the results and to highlight the non-linear effect, we estimate a model that considers the transition to be abrupt (Panel Transition Regression) and a smooth transition model (Panel Smooth Transition Regression) developed by Hansen (1999). The consideration of a gradual change has been highlighted by Gonzàles et al. (2005).

Several linearity tests are proposed in the literature. Considering the basic model estimated by the Generalized Moment Method, the test of Tsay (1989) can be specified as equations 7 and 8 below:

$$
\begin{gathered}
\text { Inequalities }_{i t}=\left(\begin{array}{l}
\alpha_{0}^{1}+\pi_{1}^{1} \text { Urban }_{i t}+\pi_{2}^{1} \operatorname{Urban}_{i t}^{2}+\mu_{i} X_{i t}+\varepsilon_{i t}^{1} \\
\alpha_{0}^{2}+\pi_{1}^{2} \operatorname{Urban}_{i t}+\pi_{2}^{2} \operatorname{Urban}_{i t}^{2}+\mu_{i} X_{i t}+\varepsilon_{i t}^{2}
\end{array}\right. \\
\text { Inequalities }_{i t}=\left(\begin{array}{l}
\alpha_{0}^{1}+\phi_{1}^{1} \text { Indus }_{i t}+\phi_{2}^{1} \text { Indus }_{i t}^{2}+\mu_{i} X_{i t}+\varepsilon_{i t}^{1} \\
\alpha_{0}^{2}+\phi_{1}^{2} \text { Indus }_{i t}+\phi_{2}^{2} \text { Indus }_{i t}^{2}+\mu_{i} X_{i t}+\varepsilon_{i t}^{2}
\end{array}\right.
\end{gathered}
$$

Let us consider $Y_{i t}$ as the explained value, $X_{i t}$ as the explanatory variable and $u_{i t}$ as the transition variable. We present the simple case of a PSTR with two regimes and two simple functions between urbanization and inequality and industrialization and inequality in Africa. The model takes the following form :

$$
Y_{i t}=\mu_{i}+\beta_{0} x_{i t}+\beta_{1}^{\prime} x_{i t} g\left(u_{i t}, \gamma, c\right)+\varepsilon_{i t}
$$

Where $\mathrm{g}\left(\mathrm{u}_{\mathrm{i} t}, \gamma, \mathrm{c}\right)$ is the transition function. This function is continuous and depends on the threshold $\mathrm{c}$ of the transition variable $\mathrm{u}_{\mathrm{it}} ; \gamma$ is the transition parameter. The transition function is a normalized and bounded function between 0 and 1 , with extreme values associated with the coefficients $\beta_{0}$ and $\left(\beta_{0}+\beta_{1}\right)$. Gonzales et al. (2005) consider this function to be a logistic transition function of the form :

$$
g\left(u_{i t}, \gamma, c\right)=\left(1+\exp \left(-\gamma \prod_{j=1}^{m}\left(u_{i t}-c\right)\right)\right)^{-1}
$$

With $\gamma>0$ and c_1 $\leq \mathrm{c} \_2 \leq \cdots \mathrm{c} \_\mathrm{m}$. The slope of the parameter $\gamma$ determines the smoothness of the transition. For $m=1$, the model exhibits the two regimes separating the lower and upper values of $u_{-}$it with a simple monotonic transition of the coefficients of $\beta_{0}$ and $\left(\beta_{0}+\beta_{1}\right)$ when $u_{-}$it increases. As the slope of the parameter increases, the transition becomes rougher and the transition function $\mathrm{g}\left(\mathrm{u}_{\mathrm{it}}, \gamma, \mathrm{c}\right)$ becomes a function of type $\mathrm{g}\left(\mathrm{u}_{\mathrm{it}}, \mathrm{c}\right)$. When the smoothing parameter tends to infinity, the transition function is equal to unity i.e. 
$\mathrm{g}\left(\mathrm{u}_{\mathrm{it}}, \mathrm{c}\right)=1$ if $\mathrm{u}_{\mathrm{it}}>\mathrm{c}$; the transition function is zero $\left(\mathrm{g}\left(\mathrm{u}_{\mathrm{it}}, \mathrm{c}\right)=0\right)$ otherwise $\left(\mathrm{u}_{\mathrm{it}}<\mathrm{c}\right)$. When $\gamma$ is close to 0 , the transition function is a constant. In this case, the PSTR tends to the PTR as developed by Hansen (1999). In general, for all values of $\mathrm{m}$, the transition function $\mathrm{g}\left(\mathrm{u}_{\mathrm{i}}, \gamma, \mathrm{c}\right)$ is constant when $\gamma$ is close to 0 .

Testing linearity in a PSTR model can be done by making the following assumptions :

$$
\begin{aligned}
& \left\{\begin{array}{c}
H_{0}: \gamma=0 \\
\text { ou } \\
H_{0}: \beta_{0}=\beta_{1}
\end{array}\right. \\
& H_{0}: \gamma \neq 0 \\
& \text { ou } \\
& H_{0}: \beta_{0} \neq \beta_{1}
\end{aligned}
$$

The null hypothesis is suitably tested by a Wald or Lagrange Multiplier (LM) test that can be supported by the maximum likelihood statistic. If we label $\mathrm{SSR}_{0}$ the sum of squares of the panel residuals under $\mathrm{H}_{0}$ (the linear panel data model with individual effects) and $\mathrm{SSR}_{1}$ the sum of the residual squares under $\mathrm{H}_{1}($ the PSTR model with two regimes), the Wald test can be written as follows:

$$
L M_{W}=\frac{N T\left(S S R_{0}-S S R_{1}\right)}{S S R_{0}} \sim X^{2}(K)
$$

The maximum likelihood test can be written as follows:

$$
L R=-2\left[\log \left(S S R_{1}\right)-\log \left(S S R_{0}\right)\right] \sim X^{2}(K)
$$

The parameters $\left(\beta_{0}, \beta_{1}, \gamma, c\right)$ of the basic model is estimated in two steps. In the first step, we removed individual effects by subtracting the means, and in the second step, we applied Nonlinear Least Squares on the transformed data to determine the parameter values that minimize the sums of squares of the residuals.

The number of regimes test is used to determine the number of regimes of the transition function. It then tests whether there is one transition function $\left(\mathrm{H}_{-} 0: \mathrm{r}=1\right)$ or whether there are at least two transition functions. To test the number of regimes we considered the model below.

$$
Y_{i t}=\mu_{i}+\beta_{0} x_{i t}+\beta_{1}^{\prime} x_{i t} g\left(u^{1}{ }_{i t}, \gamma, c\right)+\beta_{2}^{\prime} x_{i t} g\left(u^{2}{ }_{i t}, \gamma, c\right)+\varepsilon_{i t}
$$

Table 5 below reports the results of the PSTR model estimates between urbanization and inequality. The Lagrange Multiplier (LM) test and the Maximum Likelihood (ML) test reject the null hypothesis of no nonlinear effect between urbanization and inequality for all three forms of inequality. The results of the PSTR mostly confirm those obtained by the estimation of the basic model by the GMM. These results show that the $\beta_{1}^{\prime}$ coefficients are positive and significant in the urbanization, income inequality, and housing inequality relationships. The $\beta_{2}^{\prime}$ coefficients, on the other hand, are negative and significant, confirming the inverted Ushaped nature of the relationship urbanization and income inequality and environmental inequality.

Table 5: Estimation PSTR model parameters for urbanization and inequalities

\begin{tabular}{|l|c|c|c|}
\hline & $\begin{array}{c}\text { Urbanization } \\
\text { and } \\
\text { income } \\
\text { inequalities }\end{array}$ & $\begin{array}{c}\text { Urbanization } \\
\text { and } \\
\text { environmental } \\
\text { inequalities }\end{array}$ & $\begin{array}{c}\text { Urbanization } \\
\text { and } \\
\text { housing } \\
\text { inequalities }\end{array}$ \\
\hline Parameter $\boldsymbol{\beta}_{\mathbf{1}}^{\prime}$ & $0.088^{*}$ & $0.160^{*}$ & $-0.011^{* *}$ \\
& $(0.0951)$ & $(0.0120)$ & $(0.030)$ \\
\hline Parameter $\boldsymbol{\beta}_{2}^{\prime}$ & $-0.0153^{* *}$ & $-0.080^{*}$ & $0.099^{* *}$ \\
& $(0.0396)$ & $(0.0785)$ & $(0.004)$ \\
\hline Parameter c & 45.62 & 35.56 & 28.36 \\
\hline Estimation of model coefficients & \multicolumn{3}{|c|}{} \\
\hline GDP/Habitant & $-0.004^{* *}$ & $-0.015^{*}$ & $0.038^{*}$ \\
& $(0.0614)$ & $(0.0863)$ & $(0.053)$ \\
\hline Domestic investment & $0.127^{*}$ & $0.072^{*}$ & -0.016 \\
& $(0.0633)$ & $(0.054)$ & $(0.018)$ \\
\hline Foreign direct investment & -0486 & -0.130 & $0.013^{*}$ \\
& $(0.155)$ & $(0.123)$ & $(0.074)$ \\
\hline Unemployment & $0.013^{* *}$ & $-0.008^{* *}$ & $0.005^{* *}$ \\
\hline
\end{tabular}




\begin{tabular}{|c|c|c|c|}
\hline & $(0.0174)$ & $(0.0254)$ & $(0.018)$ \\
\hline $\begin{array}{l}\text { Governance normalized } \\
\text { index }\end{array}$ & $\begin{array}{c}0.519 \\
(1.813)\end{array}$ & $\begin{array}{c}1.554 \\
(3.094)\end{array}$ & $\begin{array}{c}2.584 \\
(0.707)\end{array}$ \\
\hline $\begin{array}{l}\text { Democracy normalized } \\
\text { index }\end{array}$ & $\begin{array}{l}0.0960 \\
(1.688)\end{array}$ & $\begin{array}{c}0.373 \\
(1.494)\end{array}$ & $\begin{array}{l}-1.313 \\
(0.996)\end{array}$ \\
\hline \multicolumn{4}{|l|}{ Linearity test } \\
\hline$L M$ with $m=1$ & $\begin{array}{l}5.33 * * * \\
(0.000)\end{array}$ & $\begin{array}{l}4.861 * * \\
(0.016)\end{array}$ & $\begin{array}{c}1.654 * * * \\
(0.000)\end{array}$ \\
\hline$L M$ with $m=2$ & $\begin{array}{l}2.56^{* * * *} \\
(0.000)\end{array}$ & $\begin{array}{l}1.825 * * * \\
(0.000)\end{array}$ & $\begin{array}{l}1.145 * * \\
(0.025)\end{array}$ \\
\hline LR avec $m=1$ & $\begin{array}{c}21.54 * * * \\
(0.000)\end{array}$ & $\begin{array}{c}16.52 * * * \\
(0.000)\end{array}$ & $\begin{array}{l}2.06 * * * \\
(0.000)\end{array}$ \\
\hline LR with $m=2$ & $\begin{array}{c}19.26 * * * \\
(0.000)\end{array}$ & $\begin{array}{c}12.56^{* * * *} \\
(0.000)\end{array}$ & $\begin{array}{c}7.125 * * * * \\
(0.000)\end{array}$ \\
\hline \multicolumn{4}{|l|}{ Test of regime number } \\
\hline$L M$ & $\begin{array}{l}6.24 * * \\
(0.018)\end{array}$ & $\begin{array}{l}0.235^{*} \\
(0.061)\end{array}$ & $\begin{array}{c}0.652 * * * \\
(0.000)\end{array}$ \\
\hline$L R$ & $\begin{array}{c}26.09 * * * \\
(0.000)\end{array}$ & $\begin{array}{l}7.265 * * * \\
(0.000)\end{array}$ & $\begin{array}{l}1.564 * * \\
(0.031)\end{array}$ \\
\hline Transition parameter $\gamma$ & 1.1481 & 0.8621 & 0.6421 \\
\hline Observations & 1702 & 1605 & 1435 \\
\hline
\end{tabular}

Notes : *p<0.1;**p<0.05;***p<0.01; P-value are reported in brackets.

Source : Authors.

The increase in the urban population in Africa increases income inequality up to the $45.62 \%$ threshold. Beyond this threshold, there is a gradual reduction in the said inequalities. As the urban population grows, income-generating activities are created that help to reduce the gap between rich and poor. However, it is important to note that the transition is slow. This is confirmed by the value of the transition parameter $(\gamma=1.14)$. The hypothesis that urbanization has an impact on inequality has been verified by Eeckhout et al., (2010).

Based on the principle that the increase in the urban population increases environmental inequalities, our results show that this principle is verified in Africa. Indeed, the increase in the urban population to $35.56 \%$ is accompanied by an increase in the poor management of household waste in urban areas. The results of the estimations confirm that the transition is weak, i.e., smooth with respect to the value of the smoothing parameter $(\gamma=0.86)$.

The results of the impact of urbanization on habitat inequality are somewhat contrary to those of the SGMM The data suggest a definitive U-shape of the curve linking urbanization and habitat inequality in Africa (Wu and Rao, 2017). Indeed, to the left of the $28.36 \%$ urbanization rate threshold, there is a negative impact on habitat inequality. But when the urbanization rate exceeds the $28.36 \%$ threshold, the number of slums increases. This critical urbanization threshold is far exceeded in some African countries. The transition between urbanization and settlement inequality is smooth in terms of the value of the smoothing parameter $(\gamma=0.64)$.

Table 6 reports the results of the PSTR model estimates between industrialization and inequality. The test for non-linearity between industrialization and the three forms of inequality is identical to that found in the case of the analysis of non-linearity between urbanization and inequality. Indeed, the Lagrange Multiplier (LM) and Maximum Likelihood (ML) tests reject the null hypothesis of no non-linear effect between industrialization and inequality for the three forms of inequality. It is as if industrialization has a specific impact before a certain threshold and then has a different impact after this identified threshold. In the case of industrialization, the results of the PSTR largely confirm those obtained by the S-GMM. First, a negative and significant impact is obtained. A positive and negative impact is secondly obtained. This confirms the $\mathrm{U}$-shaped nature of the relationship between industrialization and inequality. 
Industrial transformation reduces income inequality up to the threshold of $24.55 \%$. Beyond this threshold, industrialization will have a positive impact on income gaps in Africa. Above this threshold, an income gap remains. Furthermore, it is important to mention that the transition between the two regimes is smooth. This is confirmed by the value of the transition parameter $(\gamma=1.015)$. The impact of the structural transformation on environmental inequality is negative before the threshold of $21.60 \%$. It becomes positive after this threshold. Everything happens as if industrial production, especially in urban centers, increases air pollution. Among the three industrialization thresholds identified, industrial transformation will quickly have an impact on the environment. The value of the transition parameter is $\gamma=0.926$. This result reveals the dilemma that African governments need to resolve.

Industrial transformation before an industrialization rate of $32.75 \%$ will contribute to a reduction in housing inequalities. After this threshold, the attractiveness of the industrial zone, the construction of which has generated positive externalities, will contribute to the spatial occupation of populations. As in the two previous cases, the transition from negative to positive impact is small as shown by the value of the transition parameter $\gamma=0.806$.

Table 6: Estimation PSTR model parameters for industrialization and inequalities

\begin{tabular}{|c|c|c|c|}
\hline & $\begin{array}{c}\text { Industrialization } \\
\quad \text { and } \\
\text { income inequalities }\end{array}$ & $\begin{array}{c}\text { Industrialization } \\
\text { and } \\
\text { environmental } \\
\text { inequalities }\end{array}$ & $\begin{array}{c}\text { Industrialization } \\
\text { and } \\
\text { housing } \\
\text { inequalities }\end{array}$ \\
\hline Parameter $\boldsymbol{\beta}_{1}^{\prime}$ & $\begin{array}{l}-0.0104 * * \\
(0.04171)\end{array}$ & $\begin{array}{c}-0.080^{* *} \\
(0.040)\end{array}$ & $\begin{array}{c}-0.0151 * * \\
(0.0157)\end{array}$ \\
\hline Parameter $\boldsymbol{\beta}_{2}^{\prime}$ & $\begin{array}{l}0.2112 * \\
(0.0954)\end{array}$ & $\begin{array}{l}0.0247 * * \\
(0.0413)\end{array}$ & $\begin{array}{l}0.1576^{*} \\
(0.0871)\end{array}$ \\
\hline \begin{tabular}{l|l} 
Parameter $c$ & \\
\end{tabular} & 24.55 & 21.60 & 32.75 \\
\hline \multicolumn{4}{|c|}{ Estimation of model coefficients } \\
\hline GDP/Habitant & $\begin{array}{l}-0.1641 \\
(0.1568)\end{array}$ & $\begin{array}{l}-0.2179 * \\
(0.0564)\end{array}$ & $\begin{array}{c}-0.1373^{*} \\
(0.014)\end{array}$ \\
\hline Domestic investment & $\begin{array}{c}-0.2011 * * \\
(0.0138)\end{array}$ & $\begin{array}{c}-0.069 * \\
(0.050)\end{array}$ & $\begin{array}{l}-0.1506^{*} \\
(0.073)\end{array}$ \\
\hline Foreign direct investment & $\begin{array}{l}-0.497 \\
(0.517)\end{array}$ & $\begin{array}{l}-0.0402 \\
(0.1906)\end{array}$ & $\begin{array}{c}0.067 \\
(0.1247)\end{array}$ \\
\hline Unemployment & $\begin{array}{l}0.1259 * \\
(0.0548)\end{array}$ & $\begin{array}{l}0.0491 * * \\
(0.0352)\end{array}$ & $\begin{array}{c}0.0232 * * \\
(0.019)\end{array}$ \\
\hline $\begin{array}{l}\text { Governance normalized } \\
\text { index }\end{array}$ & $\begin{array}{c}0.264 \\
(0.7079)\end{array}$ & $\begin{array}{c}0.436 \\
(0.4251)\end{array}$ & $\begin{array}{l}0.808 * * \\
(0.032)\end{array}$ \\
\hline $\begin{array}{l}\text { Democracy normalized } \\
\text { index }\end{array}$ & $\begin{array}{c}0.1528 \\
(0.6363)\end{array}$ & $\begin{array}{c}-0.795 * * * \\
(0.000)\end{array}$ & $\begin{array}{l}-4.602 \\
(0.341)\end{array}$ \\
\hline \multicolumn{4}{|l|}{ Test de linéarité } \\
\hline LM with $m=1$ & $\begin{array}{l}1.068 * * * \\
(0.000)\end{array}$ & $\begin{array}{c}2.104 * * \\
(0.041)\end{array}$ & $\begin{array}{l}2.541 * * * \\
(0.000)\end{array}$ \\
\hline$L M$ with $m=2$ & $\begin{array}{c}1.623 * * * \\
(0.000)\end{array}$ & $\begin{array}{c}1.3401 * * * \\
(0.000)\end{array}$ & $\begin{array}{c}1.389 * * * \\
(0.000)\end{array}$ \\
\hline LR with $m=1$ & $\begin{array}{c}4.356 * * * \\
(0.000)\end{array}$ & $\begin{array}{c}3.064 * * * \\
(0.000)\end{array}$ & $\begin{array}{l}1.965 * * * \\
(0.000)\end{array}$ \\
\hline LR with $m=2$ & $\begin{array}{l}13.54 * * * \\
(0.000)\end{array}$ & $\begin{array}{l}5.2014 * * * \\
(0.000)\end{array}$ & $\begin{array}{c}8.365 * * * \\
(0.000)\end{array}$ \\
\hline \multicolumn{4}{|l|}{ Test of regime number } \\
\hline$L M$ & $\begin{array}{l}0.468 * * \\
(0.018)\end{array}$ & $\begin{array}{c}0.8201 * \\
(0.091)\end{array}$ & $\begin{array}{c}0.912 * * * \\
(0.000)\end{array}$ \\
\hline$L R$ & $\begin{array}{l}4.562 * * * \\
(0.000)\end{array}$ & $\begin{array}{l}2.1054 * * * \\
(0.000)\end{array}$ & $\begin{array}{c}3.642 * * * \\
(0.000)\end{array}$ \\
\hline
\end{tabular}




\begin{tabular}{|l|c|c|c|}
\hline Transition parameter $\boldsymbol{\gamma}$ & 1.015 & 0.926 & 0.806 \\
\hline Observations & 1702 & 1736 & 1702 \\
\hline
\end{tabular}

Notes :*p<0.1;**p<0.05;*** $p<0.01 ; P$-value are reported in brackets.

Source : Authors.

The results obtained by the PTR corroborate those of the PSTR and, as required by the test procedure, form the basis of the smooth transition test. Unemployment and the quality of governance increase inequality. Foreign direct investment does not affect inequality. Democracy shows different results for different forms of inequality.

\section{Conclusion and policy Recommendations}

This paper has assessed the effects of urbanization and industrialization on disaggregated indices of inequality (income, environmental, and housing). Although exacerbated, to the best of our knowledge, these inequalities have not been the subject of simultaneous empirical investigations. We implemented it on a panel of 48 African countries over the 1980-2016 time horizon using the Generalized System Moment Method. Two main results are obtained: $(i)$ urbanization is positively and significantly related to inequality in Africa up to a certain threshold; (ii) industrialization significantly reduces inequality in Africa. In other words, countries with a fairly high rate of urbanization experience a rise in social, economic and environmental disparities.

To reach these results, we mobilized a theory anchored on developments related to the Kuznets curve. A dynamic panel data model was used as the econometric basis, with a quadratic (non-linear) specification. The results of the basic model remained robust by applying the PTR and PSTR models. Their implementation allowed us to determine the critical thresholds of urbanization and industrialization that could reveal a decoupling effect on the different declines of inequalities. Specifically, above a critical threshold of $45.62 \%$ of the urbanization rate, income inequalities are exacerbated, compared with $33.56 \%$ for environmental inequalities and $28.38 \%$ for housing inequalities. Below the respective thresholds of $24.55 \%, 21.60 \%$ and $32.75 \%$, industrialization significantly reduces inequalities. Above these thresholds, industrialization would increase inequality provided that good industrial transformation policies are in place.

Four main recommendations can be made: $(i)$ economic, social and environmental disparities must be taken into account; (ii) the implementation of sanitation or waste flow management policies must contribute to reducing inequalities between rich and poor neighborhoods; (iii) in the search for sustainable cities, the decoupling of socioeconomic, demographic and territorial growth from resource scarcity and environmental degradation requires the management of public actions; (iv) Africa's industrial transformation must aim not only at increasing productivity but also at improving the quality of life of the population.

\section{Références bibliographiques}

1. Anyanwu. J.-C., ANDREW. E., ERHIJAKPOR. O., \& EMEKA. O. (2016). Empirical Analysis of the Key Drivers of Income Inequality in West Africa. African Development Review, 28(1), 18-38.

2. Arellano. M., \& Bond. S. (1991). Some Tests of Specification for Panel Data: Monte Carlo Evidence and an Application to Employment Equations. Review of Economic Studies, 58, 277-297.

3. Arellano. M., \& Bover O (1995). Another Look at the Instrumental-Variable Estimation of ErrorComponents Models. Journal of Econometrics, 68, 29-52.

4. BAfD/OCDE/PNUD (2017). Perspectives Economiques en Afrique 2017, Entrepreneuriat et Industrialisation, Editions OCDE, Paris, 344p.

5. Behrens. K., Mion. G., Murata. Y., \& Südekum. J. (2012) Spatial frictions. CEPR Discussion Paper \#8572.

6. Blundell. R., \& Bond. S. (1998). Initial Conditions and Moment Restrictions in Dynamic Panel Data Models. Journal of Econometrics, 87, 115-143.

7. Bonaiuto. M., Aiello. A., Perugini. M., Bonnes. M., \& Ercolani. P. (1999). Multidimensional perception of residential environment. Quality and neighborhood attachment in the urban environment». Journal of Environmental Psychology, 19, 331-352. 
8. Brunori. P., Palmisano. F., \& Peragine. V. (2015). Inequality of opportunity in Sub-Saharan Africa in Policy Research Working Paper No. 7782. Washington, DC : World Bank.

9. Chen. Z., \& Zhou. Y. (2005). Income distribution during system reform and economic development in China: The status and trend of income inequality of Chinese residents. New York: Nova Science Pub Inc.

10. Chen. X.-Y., (2010). Urbanization, industrialization and urban-rural income gap-Based on SVAR model. Economic Latitude and Longitude, 6, 21-24.

11. Chen. B., Dan. L., \& Ming. L. (2018). City size, migration and urban inequality in China. https://doi.org/10.1016/i.chieco.2018.05.001

12. Fosu. A. (2018). Economic Structure, Growth, and Evolution of Inequality and Poverty in Africa: An Overview». Journal of African Economies, 27(1), 1-9.

13. Kanbur. R., \& Zhuang. J. (2013). Urbanization and inequality in Asia». Asian Development Review.

14. Kuznets. S. (1955). Economic growth and income inequality. American Economic Review, 45, 1-28.

15. Lachaud. J.-P. (2006). Urbanisation, pauvreté et capacités : nouveaux défis des stratégies de développement ? Une approche spatio-temporelle au Burkina Faso. Revue d'Économie Régionale \& Urbaine, 3, 455-488.

16. Liddle. B. (2017) Urbanization and Inequality/Poverty. Urban Science 1, doi:10.3390/urbansci1040035.

17. Mahmood. S., \& Noor. Z.-M. (2014). Human Capital and Income Inequality in Developing Countries: New Evidence Using the Gini Coefficient». Journal of Entrepreneurship and Business, 2(1), 40-48.

18. Mehic. M., (2018). Industrial employment and income inequality: Evidence from panel data, $<$ ![CDATA[Structural Change and Economic Dynamics]] > (2018), https://doi.org/10.1016/j.strueco.2018.02.006

19. Meunié. A. (2004). Controverses autour de la courbe environnementale de Kuznets, IFREDEGRES/CED, Université Montesquieu Bordeaux IV Document de Travail/107/2004.

20. ONU-Habitat, (2014), L'état des villes africaines 2014 : Réinventer la transition urbaine, Nairobi, Kenya, 278p.

21. Shimeles. A., \& Nabassaga. T. (2018). Why Is Inequality High in Africa? Journal of African Economies, 27(1), 108-126.

22. Tsay. R. (1989). Testing and Modelling Threshold Autoregressive Processes. Journal of the America Statistical Association, 84, 231-240.

23. Wei. Y.-D., Li. H., \& Yue. W. (2017). Urban land expansion and regional inequality in transitional China. Landscape and Urban Planning, 163, 17-31.

24. WHALLEY J, ZHANG S (2007) A numerical simulation analysis of (Hukou) labour mobility restrictions in China. Journal of Development Economics 83(2): 392-410.

25. Wooldridge, J. (2013). Introductory Econometrics: A Modern Approach (Fifth Edition). Boston Cengage Learning Custom, $910 \mathrm{p}$.

26. WU, D., \& RAO, P. (2017) Urbanization and Income Inequality in China: An Empirical Investigation at Provincial Level. Soc Indic Res, 131, 189-214.

\section{Appendix}

\section{Appendix 1 : List of countries}

Angola, Benin, Botswana, Burkina-Faso, Burundi, Cap-Verde, Cameroon, CAR, Chad, Comores, Congo, Democratic Republic of Congo, Cote d'ivoire, Djibouti, Erythrea, Equatorial Guinea, Ethiopia, Gabon, Gambia, Ghana, Guinea, Guinea Bissau, Kenya, Lesotho, Liberia, Madagascar, Malawi, Mali, Mauritania, Maurice, Mozambique, Namibia, Niger, Nigeria, Ouganda, Rwanda, Sao Tomé and Principe, Senegal, Seychelles, Sierra Leone, Soudan, South Africa, Sudan, Swaziland, Tanzania, Togo, Zambia, Zimbabwe.

\section{Appendix 2 : Correlation matrix}

\section{Urbanization and inequalities}




\begin{tabular}{|c|c|c|c|c|c|c|c|c|c|}
\hline & Inc-ine & Urbanl & Urban2 & $G D P / H b t$ & $\begin{array}{l}\text { Dom- } \\
\text { inv }\end{array}$ & $F D I$ & Unempl & Gover & Democ \\
\hline Inc-ine & 1.0000 & & & & & & & & \\
\hline Urbanl & $0.0529 *$ & 1.0000 & & & & & & & \\
\hline Urban2 & -0.0324 & $0.9607 *$ & 1.0000 & & & & & & \\
\hline$G D P / H b t$ & 0.0373 & 0.02171 & 0.0061 & 1.0000 & & & & & \\
\hline Dom-inv & $0.2586^{*}$ & $0.5438 *$ & $0.5433 *$ & $0.1125 *$ & 1.0000 & & & & \\
\hline$F D I$ & -0.0374 & $0.3593 *$ & $0.3338 *$ & 0.0211 & $0.3767 *$ & 1.0000 & & & \\
\hline Unemployment & 0.0062 & $0.2775 * *$ & $0.2342 *$ & $0.2771 *$ & $0.3138 *$ & $0.3179 *$ & 1.0000 & & \\
\hline Governance & -0.0429 & $0.0808 *$ & $0.0882 *$ & -0.0053 & $0.0863 *$ & -0.0489 & -0.0167 & 1.0000 & \\
\hline \multirow[t]{2}{*}{ Democracy } & 0.0610 & $0.1032 *$ & $0.1048^{*}$ & 0.0081 & $0.1222 *$ & -0.0354 & -0.0097 & $0.8573 *$ & 1.0000 \\
\hline & Env-ine & Urbanl & Urban2 & $G D P / H b t$ & $\begin{array}{l}\text { Dom- } \\
\text { inv }\end{array}$ & $F D I$ & Unempl & Gover & Democ \\
\hline Env-ine & 1.0000 & & & & & & & & \\
\hline Urban1 & 0.0199 & 1.0000 & & & & & & & \\
\hline Urban2 & 0.0255 & $0.9607 *$ & 1.0000 & & & & & & \\
\hline$G D P / H b t$ & -0.0254 & 0.0217 & 0.0061 & 1.0000 & & & & & \\
\hline Dom-inv & $0.2216^{*}$ & $0.5438 *$ & $0.5433 *$ & $0.1125 *$ & 1.0000 & & & & \\
\hline$F D I$ & 0.0214 & $0.3593 *$ & $0.3338 *$ & 0.0211 & $0.3767 *$ & 1.0000 & & & \\
\hline Unemployment & $0.0690 *$ & $0.2775^{*}$ & $0.2342 *$ & $0.2771 *$ & $0.3138 *$ & $0.3179 *$ & 1.0000 & & \\
\hline Governance & 0.0080 & $0.0808 * *$ & $0.0882 *$ & -0.0053 & $0.0863 *$ & -0.0489 & -0.0167 & 1.0000 & \\
\hline \multirow[t]{2}{*}{ Democracy } & 0.0014 & $0.1032 *$ & $0.104 *$ & 0.0081 & $0.1222 *$ & -0.0354 & -0.0097 & $0.8573 *$ & 1.0000 \\
\hline & $\begin{array}{l}\text { Hou- } \\
\text { ine }\end{array}$ & Urban1 & Urban2 & $G D P / H b t$ & $\begin{array}{c}\text { Dom- } \\
\text { inv }\end{array}$ & $F D I$ & Unempl & Gover & Democ \\
\hline Hou-ine & 1.0000 & & & & & & & & \\
\hline Urban1 & 0.0197 & 1.0000 & & & & & & & \\
\hline Urban2 & 0.0136 & $0.9607 *$ & 1.0000 & & & & & & \\
\hline$G D P / H b t$ & 0.0265 & 0.0217 & 0.0061 & 1.0000 & & & & & \\
\hline Dom-inv & -0.0384 & $0.5438 *$ & $0.5433 *$ & $0.1125 *$ & 1.0000 & & & & \\
\hline$F D I$ & $\begin{array}{c}- \\
0.0790 *\end{array}$ & $0.3593 *$ & $0.3338 *$ & 0.0211 & $0.3767 *$ & 1.0000 & & & \\
\hline Unemployment & $\begin{array}{c}- \\
0.0660 *\end{array}$ & $0.2775 *$ & $0.2342 *$ & $0.2771 *$ & $0.3138 *$ & $0.3179 *$ & 1.0000 & & \\
\hline Governance & $0.0804 *$ & $0.0808 * *$ & $0.0882 *$ & -0.0053 & $0.0863 *$ & -0.0489 & -0.0167 & 1.0000 & \\
\hline Democracy & $0.0520 *$ & $0.1032 *$ & $0.1048 *$ & 0.0081 & $0.1222 *$ & -0.0354 & -0.0097 & $0.8573 *$ & 1.0000 \\
\hline
\end{tabular}

Notes : *p $<0.1 ; * * p<0.05 ; * * * p<0.01$.

Source: Authors.

\begin{tabular}{|c|c|c|c|c|c|c|c|c|}
\hline & Inc-ine & Urbanl & Urban2 & $G D P / H b t$ & $\begin{array}{c}\text { Dom- } \\
\text { inv }\end{array}$ & $F D I$ & Unempl & Gover \\
\hline Inc-ine & 1.0000 & & & & & & & \\
\hline$M V A$ & 0.0209 & 1.0000 & & & & & & \\
\hline$G D P / H b t$ & 0.0316 & 0.0274 & 1.0000 & & & & & \\
\hline Dom-inv & 0.0253 & $0.2776^{*}$ & $0.0845^{*}$ & 1.0000 & & & & \\
\hline$F D I$ & $0.0811 *$ & $0.3840 *$ & $0.0882 *$ & $0.2117 *$ & 1.0000 & & & \\
\hline Unemployment & -0.0050 & $0.2867 *$ & $0.2615^{*}$ & $0.1669 *$ & $0.2186^{*}$ & 1.0000 & & \\
\hline Governance & 0.0050 & $0.0767 *$ & -0.0104 & $0.0537 *$ & $\begin{array}{c}- \\
0.0466 *\end{array}$ & $\begin{array}{c}- \\
0.0696 *\end{array}$ & 1.0000 & \\
\hline Democracy & 0.0016 & $0.1021 *$ & 0.0025 & $0.0888 *$ & - & - & $0.8573 *$ & 1.0000 \\
\hline
\end{tabular}




\begin{tabular}{|c|c|c|c|c|c|c|c|c|}
\hline & Env-ine & Urban1 & Urban2 & $G D P / H b t$ & $\begin{array}{c}\text { Dom- } \\
\text { inv }\end{array}$ & $F D I$ & Unempl & Gover \\
\hline Env-ine & 1.0000 & & & & & & & \\
\hline$M V A$ & 0.0062 & 1.0000 & & & & & & \\
\hline$G D P / H b t$ & -0.0276 & $0.1980 *$ & 1.0000 & & & & & \\
\hline Dom-inv & $0.1064 *$ & $0.0491 *$ & $0.0845 *$ & 1.0000 & & & & \\
\hline$F D I$ & 0.0457 & -0.0042 & $0.0882 *$ & $0.2117 *$ & 1.0000 & & & \\
\hline Unemployment & $0.0490^{-}$ & 0.0430 & $0.2615 *$ & $0.1669 *$ & $0.2186^{*}$ & 1.0000 & & \\
\hline Governance & 0.0260 & 0.0178 & -0.0104 & $0.0537 *$ & $\begin{array}{c}- \\
0.0466 *\end{array}$ & $\begin{array}{c}- \\
0.0696 *\end{array}$ & 1.0000 & \\
\hline Democracy & 0.0248 & 0.0347 & 0.0025 & $0.0888 *$ & $0.0485 *$ & $\begin{array}{c}- \\
0.0558 * \\
\end{array}$ & $0.8573 *$ & 1.0000 \\
\hline & $\begin{array}{l}\text { Hou- } \\
\text { ine }\end{array}$ & Urbanl & Urban 2 & $G D P / H b t$ & $\begin{array}{c}\text { Dom- } \\
\text { inv }\end{array}$ & $F D I$ & Unempl & Gover \\
\hline Hou-ine & 1.0000 & & & & & & & \\
\hline$M V A$ & 0.0327 & 1.0000 & & & & & & \\
\hline$G D P / H b t$ & 0.0234 & $0.1980 *$ & 1.0000 & & & & & \\
\hline Dom-inv & -0.0218 & $0.0491 *$ & $0.0845 *$ & 1.0000 & & & & \\
\hline$F D I$ & $\begin{array}{c}- \\
0.0477 *\end{array}$ & -0.0042 & $0.0882 *$ & $0.2117 *$ & 1.0000 & & & \\
\hline Unemployment & -0.0401 & 0.0430 & $0.2615 *$ & $0.1669 *$ & $0.2186 *$ & 1.0000 & & \\
\hline Governance & $0.0744 *$ & 0.0178 & -0.0104 & $0.0537 *$ & $0.0466 *$ & $\begin{array}{c}- \\
0.0696 *\end{array}$ & 1.0000 & \\
\hline Democracy & 0.0460 & 0.0347 & 0.0025 & $0.0888 *$ & $\stackrel{-}{-} .0485 *$ & $\begin{array}{c}- \\
0.0558 *\end{array}$ & $0.8573 *$ & 1.0000 \\
\hline
\end{tabular}

Industri alizatio n and inequali ties Notes : $* p<$ $0.1 ; * * p$ $<0.05$; $* * * p<$ 0.01 . Source : Authors. 